\title{
İçsel Pazarlamanın İş Tatmini ve İşten Ayrılma Niyeti Üzerindeki Rolü: Spor ve Fiziksel Etkinlik İşletmeleri Üzerine Ampirik Bir İnceleme
}

\author{
The Role of Internal Marketing on Job Satisfaction and Turnover Intention: \\ An Empirical Investigation of Sport and Physical Activity Organizations
}

\author{
Süleyman Murat YILDIZ
}

\begin{abstract}
ÖZET
İnsanların değişen yaşam tarzı, yükselen tüketici bilinci, sağlık ve fiziksel uygunluğa yönelik ilgisinden dolayı spor ve fiziksel etkinlik işletmelerinin hizmet sektörü içerisindeki pazar payı gün geçtikçe artmaktadır. Bu bağlamda, spor ve fiziksel etkinlik işletmelerinde içsel pazarlamanın iş tatmini ve işten ayrılma niyeti üzerindeki rolünün incelenmesi bu araştırmanın amacını oluşturmaktadır. Araştırmada veri toplama aracı olarak; Foreman ve Money'in (1995) içsel pazarlama ölçeği, Chang ve Chang'ın (2007) iş tatmini ölçeği, Landau ve Hammer'in (1986) işten ayrılma niyeti ölçeği kullanılmıştır. Veriler, ticari olarak faaliyet gösteren fitness merkezlerinde görev yapan antrenörlerden $(\mathrm{N}=142)$ elde edilmiştir. Araştırma sonuçları, içsel pazarlama ile iş tatmini arasında anlamlı ve pozitif bir ilişkinin varlığını; işten ayrılma niyeti ile içsel pazarlama ve iş tatmini arasında ise anlamlı ve negatif bir ilişkinin varlığını ortaya koymuştur. Ayrıca araştırma sonuçları iş tatmininin içsel pazarlama ve işten ayrılma niyeti arasında tam aracılık etkisi olduğunu da göstermiştir.
\end{abstract}

Anahtar kelimeler: Içsel pazarlama, iş tatmini, işten ayrılma niyeti, spor işletmeleri.

\section{GiRiş}

Spor ve fiziksel etkinlik hizmetleri sunan işletmeler hizmet endüstrisinin en ilgi çekici sektörleri arasında yer almaktadır. İnsanların performans, sağlık ve fiziksel uygunluk sağlayan aktivitelere olan ilgisinin son zamanlarda daha da artması ile birlikte bu hizmetleri üreten işletmelerin çoğalması, diğer sektörlerde olduğu gibi spor ve fiziksel etkinlik sektöründe de rekabeti gündeme getirmiştir. Yoğun rekabet ortamının yaşandığı günümüzde, rekabette başarılı olan işletmeler hayatta kalırken, başarısız olanlar pazardan çekilmek durumunda kalmaktadırlar (Grönroos, 1990). Dolayısıyla, spor ve fiziksel etkinlik hizmetleri sunan işletmeler de, varlıklarını sürdürebilmeleri için daha etkin pazarlama stratejileri

\begin{abstract}
Market share of sport and physical activity organizations in the services sector has been steadily increasing because of changing consumer lifestyles and elevated levels of consumer awareness and interest in health and fitness. Therefore, the objective of this study was to investigate the role of internal marketing on employee job satisfaction and turnover intentionin the sport and physical activity organizations. Internal Marketing (Foreman and Money, 1995), job satisfaction (Chang and Chang, 2007) and turnover intention (Landau and Hammer, 1986) scales were used as data collection instruments. The data for the study were collected from fitness trainers $(\mathrm{N}=142)$ who were employed in commercial fitness centers. The study results demonstrate that there is a significant positive relationship between internal marketing and job satisfaction. The results also show that turnover intention is significantly influenced by internal marketing and job satisfaction. Furthermore, the effects of internal marketing on turnover intention were fully mediated by job satisfaction.
\end{abstract}

Keywords: Internal marketing, job satisfaction, turnover intention, sport organizations.

geliştirme zorunluluğuyla karşı karşıyadırlar (Yıldız ve Tüfekçi, 2010).

Spor ve fiziksel etkinlik hizmetleri kamu ve özel işletmeler marifetiyle topluma sunulmaktadır. Spor kulüpleri, spor okulları, fitness merkezleri, spor merkezleri, açık ve kapalı spor tesisleri bu işletmelerden bazılarıdır. Bu işletmelerde sunulan hizmetler, -diğer sektörlerdeki hizmetlere göreözellikle antrenörler ile müşteriler (fiziksel aktivite katılımcıları, sporcular) arasında, uzun süreye dayanan ve aynı tesiste gerçekleşen yoğun temas ve paylaşımı gerektirmektedir. Ayrıca müşterilerde katılım sık, uzun süreli ve rekabetçi olabilmektedir. Bu özellikler göz önüne alındığında, spor ve fiziksel etkinlik işletmelerinde müşterilerin tatmini için, bir taraftan 
hizmet sunumunun temel aktörü olan antrenörlerin daha fazla çaba göstermesine ihtiyaç duyulmakta, diğer taraftan işletmelerin iyi antrenörleri uzun süre elde tutabilmesi gerekmektedir (Yıldız, 2011).

Çalışanların işten ayrılması, her tip organizasyonda görülen yaygın bir sorundur (Yin-Fah, Foon, Chee-Leong ve Osman, 2010) ve bu sorun hizmet sektöründe daha fazladır (Wasmuth ve Davis, 1993). Örneğin 1983 yılında Kuzey Amerika'da 20 otel üzerinde yapılan bir araştırmada gönüllü olarak işten ayrılma oranı \%60 olarak görülmüştür (Wasmuth ve Davis, 1983). Eylül 2005-Ağustos 2006 arasındaki verilere göre, Amerika Birleşik Devletleri'ndeki serbest zaman ve konaklama sektöründeki gönüllü olarak işten ayrılma oranı \%52,2'dir (www.wf1broward. com). Bu oranlardan da görüleceği üzere, hizmet sektöründeki işten ayrılma niyeti oldukça yüksektir. Dolayısıyla, hizmet sektörü içerisinde yer alan her işletmede görüldüğü gibi spor ve fiziksel etkinlik işletmelerinde de işten ayrılma niyeti üzerinde etkili olabilecek olgular önem kazanmaktadır (Yıldız, 2013).

Hizmet sektöründe en önemli sermayenin insan kaynağı olduğu gün geçtikçe daha iyi anlaşılmaya başlanmıştır (Çarıkçı ve Oksay, 2004). Çalışanların iş tutumu ve davranışları hizmet kalitesi ve müşteri tatminini etkilemektedir (Joseph, 1996). Dolayısıyla, hizmet sektörü içerisinde yer alan spor ve fiziksel etkinlik işletmelerinde bulunan performansı yüksek çalışanların istikrarlı bir şekilde işe devam etmeleri, işletme performansını doğrudan etkileyecektir. Bu noktada, personelin iş tatmini ve işten ayrılma niyeti üzerinde etkili olan değişkenler önem kazanmaktadır. $\mathrm{Bu}$ araştırmanın konusu olan; içsel pazarlama, iş tatmini ve işten ayrılma niyeti değişkenleri arasındaki bağlantıların ortaya konulması, spor yönetimi ve pazarlaması bağlamında, literatüre ve sektöre sağlayacağı katkı bakımından önemli görülmektedir. Buradan hareketle, spor ve fiziksel etkinlik işletmelerinde içsel pazarlamanın iş tatmini ve işten ayrılma niyeti üzerindeki rolünün incelenmesi bu araştırmanın amacını oluşturmaktadır.

\section{TEORIK ÇERÇEVE}

\section{1. İçsel Pazarlama}

Günümüzdeki pazarlama anlayışı işletmedeki çalışanları bir müşteri gibi ele almakta ve bunları iç pazar olarak görmektedir (Gummesson, 1987; Rafiq ve Ahmed, 1993). Bu bağlamda içsel pazarlama, işletmenin dışsal pazarlama için geliştirdiği pazarlama araç ve tekniklerinin çalışanlara uygulanmasını ifade etmektedir (Lings, 2004). İçsel pazarlama, dışsal pazarlamada başarıya ulaşabilmek için anahtar unsur olarak görülmekte (Greene,
Walls ve Schrest, 1994) ve işletme ve çalışanları arasındaki etkili bir iç mübadeleye odaklanmaktadır (George, 1990). İç mübadelede, işletme tarafından çalışanların motivasyonu sağlanırken, çalışanlardan da dış müşterilerin tatminine odaklanmaları beklenmektedir. Bu çerçevede, içsel pazarlama, nitelikli çalışanları işletmeye çekerek işletmede tutmayı ve onları tatmin ederek sadakatini sağlamayı ve bu süreç içerisinde müşteri odaklılığı oluşturma üzerine yoğunlaşan faaliyetleri kapsamaktadır.

Son zamanlarda pazarlama olgusunun işlemsel pazarlamadan ilişkisel pazarlamaya doğru dönüştüğü ifade edilmektedir (Berry, 1995). Illişkisel pazarlama, dış müşterilerin tatminini sağlayaraksadakatiniartırmaya, korumaya ve geliştirmeye yönelik olarak uygulanan, onlarla ilişkileri geliştirmeyi ve daha fazla iş yapmayı amaçlayan stratejik bir yaklaşımdır (Grönroos, 1994). Günümüzde ilişkisel pazarlamanın, içsel pazarlama faaliyeti içerisinde, işletmeler tarafından çalışanlara da uygulanması önemli görülmektedir (Martensen ve Gronholdt, 2006). Bunun temelinde, çalışanlara yönelik iyi işlemeyen "iç ilişkiler"in başarılı bir "dış müşteri ilişkileri"ni oluşturamayacağı yatmaktadır (Grönroos, 2000). Gummesson (2000) ve Lau ve May (1998) iç ilişkileri kazan-kazan paradigması ile ele almaktadır. Bu paradigmaya göre, işletme ile çalışanlar birbirlerini dikkate alarak karşılıklı yarar sağlarlar ve birbirlerini mağdur etmezler. Anlamlı bir birliktelik söz konusudur; bir tarafın başarısı diğer tarafın başarısı olarak görülür. Bu çerçevede bir tarafta motivasyonu ve performansı yüksek çalışanlar söz konusu iken, diğer tarafta başarılı ve karlı bir işletme yer almaktadır.

Çalışanlar hizmet üretiminde işletmelerin en önemli unsuru olarak görülmektedir (Cooper ve Cronin, 2000). Bunun sebebi, dış müşteri tatmininin oluşumunda çalışanların önemli rolünün olmasıdır (Berry, 1995). Dolayısıyla içsel pazarlama, dış müşterilerin tatmini ve sadakati için öncelikle çalışanların beklenti ve ihtiyaçlarının karşılanmasının zorunlu olduğuna dikkat çekmektedir (George, 1990). Beklenti ve ihtiyaçları karşılanan çalışanların müşteri odaklıı̆ının daha fazla olacağı ileri sürülmekte (Wagenheim ve Anderson, 2008) bunun da dış müşteriye daha kaliteli hizmet sağlamamanın önemli bir unsuru olduğu ifade edilmektedir. Diğer taraftan müşteri odaklıı̆ı̆ oluşmamış çalışanların dış müşteri tatminini olumsuz yönde etkileyeceği, bunun da dış müşteriler arasında ağızdan ağıza iletişimle işletmenin pazarlama gayretlerini olumsuz etkileyeceği öne sürülmektedir (Cooper ve Cronin, 2000). Literatürde, çalışanların müşteri odaklılığını sağlamada hangi unsurların etkili olduğu yönünde tam bir fikir birliği 
bulunmasa da (Ahmed, Rafiq ve Saad, 2003; Yıldız, 2011), nitelikliçalışanlarıçekmeve elde tutma (Ahmad, lqbal ve Sheeraz, 2012; Berry, 1995), çalışanların eğitimi, gelişimi (Cahill, 1995; Gummesson, 1991), motivasyonu (Rafiq ve Ahmed, 2000) ve daha geniş bir yaklaşımla çalışanlarla ilişkilerin gelişimini sağlayacak tüm unsurları içermektedir. Foreman ve Money (1995) içsel pazarlama öğelerini vizyon, ödül ve gelişim olmak üzere üç boyutta ele almıştır. Vizyon; işletmeninin geleceği ile ilgili arzu edilen imajın çalışanlarla paylaşılmasını, ödül; performans değerlemesini ve bunun sonucunda başarılı çalışanların ödüllendirilmesini, gelişim ise; değişen iç ve dış çevreye uyum sağlayabilmesi ve gelecekte daha iyi noktaya ulaşabilmesi için çalışanların eğitilmesini ve ihtiyaçlarının sağlanmasını ifade eder. Tüm bu boyutlar çalışanların müşteri odaklılığını sağlama hususunda motivasyonlarını artırıcı unsurlar olarak görülmektedir.

\section{2. İş Tatmini}

Çalışanlar bir iş ortamında bireysel amaçlarını gerçekleştirmek üzere zihinsel, fiziksel ve sosyal becerilerini sergilerler. Bu süreç içerisinde, iş ve iş ortamı kaynaklı, kişide duygusal olarak bir takım tepkiler meydana gelir. Bunlar zamanla doğrudan çalışanın, dolaylı olarak da işletmenin performansını olumlu veya olumsuz etkiler. Bu yüzden iş tatmini, işletmeler için önemli görülen olgular arasında yer almaktadır.

İş tatmini çalışanların genel olarak işine karşı duygusal değerlendirmelerini ifade eden bir kavramdır (Arnett, Laverie, ve Mclane, 2002). İş tatmini, çalışanların işinden beklentileri ile işletmelerinden elde ettikleri arasındaki farkın derecesi olarak ele alınmaktadır (Shiu ve Yu, 2010). Bu farka göre çalışanlar işine karşı pozitif veya negatif bir tutum sergiler. Buna göre pozitif tutum iş tatmini, negatif tutum ise iş tatminsizliği olarak değerlendirilmektedir (Saari ve Judge, 2004). Chang ve Chang (2007) iş tatmini iç ve dış tatmin olarak iki boyutta ele almaktadır. İçsel tatmin, işin çalışanda oluşturduğu duygusal ve tutumsal tatmin düzeyini ifade etmektedir. Dışsal tatmin ise, işle ilgili iyi bir çalışma ortamı, refah, yüksek maaş ve diğer ödüller gibi yönleri içermektedir.

İş tatmini dinamik bir özellik taşımaktadır. Zaman zaman artabilir veya azalabilir. Çalışanların ihtiyaç ve beklentilerine göre değişiklik gösterir. Yapılan araştırmalar, iş tatmini düşük olan çalışanların işten uzaklaştıklarını, yüksek olanların ise verimliliklerinin arttığını göstermektedir (Güney, 2012). Diğer taraftan, çalışanlarının tatmininin dış müşteri tatminini pozitif etkilediğini, bunun da işletmenin performansına olumlu etki yaptığını göstermektedir (Jeon ve Choi, 2012).

\section{3. İ̧sten Ayrılma Niyeti}

İ̧̧ ve iş ortamıçalışanlar üzerinde çeşitli etkiler bırakmaktadır. Bu etkilerden birisi de çalışanların işten ayrılma niyeti üzerinedir. İşten ayrılma niyeti esasında işten ayrımanın kendisi değil, fakat önemli göstergelerinden birisidir. İşten ayrılma niyeti bireyin işe devam etmeme ile ilgili düşüncesi, yani işe yönelik olumsuz tutumunu yansıtmaktadır. Bu tür niyetin oluşmasında bireyin geçmiş deneyimi, iş ortamı ve iş dışındaki çevre önemli yer tutar. Yetersiz ücret, beklenen terfinin gerçekleşmemesi, yönetici ile olumsuz ilişkiler, piyasada daha iyi iş fırsatı, iş güvenliği sorunu, sağlık problemi, emeklilik, tayin vb. gibi faktörler bireyin işten ayrılma niyeti üzerinde etkilidirler.

İşten ayrılma, "isteyerek ayrılma" ve "istemeyerek ayrılma" olarak iki şekilde görülmektedir (Watrous, Huffman ve Pritchard, 2006). İsteyerek ayrılma, bireysel bir tercihi ifade eder (Wells ve Peachey, 2011) ve ana sebeplerini yukarıda belirtildiği gibi iş ortamı, iş dışındaki çevre ya da bireysel faktörler oluşturur. İstemeyerek ayrılma ise, işten çıkarılma (Chang ve Chang, 2008) ya da başka bir birime gönderilmedir. $\mathrm{Bu}$ durum zayıf performans ya da uygun olmayan davranıştan dolayı meydana gelmektedir.

Çalışanın işten ayrıımasının işletmelere doğrudan ve dolaylı maliyetleri bulunmaktadır. Yeni bir personelin bulunması, işe alınması ve eğitimi gibi faaliyetler doğrudan maliyetleri içerirken; geride kalan çalışanların moralinin azalması, iş yükünün artması ve sosyal sermaye kaybı dolaylı maliyetleri içermektedir (Staw, 1980; Dess ve Shaw, 2001). Sonuç olarak, gerek iyi çalışanın işten ayrılmasıyla yaşanan insan kaynağı kaybı, gerekse devam eden iş akışını bölmesi açısından işten ayrılma niyeti organizasyonları olumsuz yönde etkilemektedir (Şahin, 2011). Dolayısıyla, işletmelerin çalışanların işten ayrılma niyetlerini ortadan kaldırmalarına yönelik çabaları istikrarlı bir hizmet sunumu açısından önemli bir konu olarak görülmektedir (Yıldız, 2013).

\section{4. İçsel Pazarlama, İş Tatmini ve İşten Ayrılma Niyeti İlişkisi}

İçsel pazarlama, iş tatmini ve işten ayrılma niyeti, işletme yönetimlerini ilgilendiren önemli konular arasında yer almaktadır. İşletme performansının belirleyicileri arasında yer alan bu konular son zamanlarda araştırmalarda daha fazla yer almaya başlamıştır. Literatürde, "içsel pazarlama ile iş tatmini", "içsel pazarlama ile işten ayrılma niyeti" ve 
"iş tatmini ile işten ayrılma niyeti" arasındaki ilişkileri inceleyen araştırmalar bulunmaktadır. Çeşitli hizmet sektörlerinde gerçekleştirilen bu araştırmalarda içsel pazarlama ile iş tatmini arasında pozitif ilişkiler (Hwang ve Chi, 2005; Yıldız, 2011), içsel pazarlama ile işten ayrılma niyeti (Chang ve Chang, 2008) ve iş tatmini ile işten ayrılma niyeti arasında ise negatif ilişkiler (Akın, 2007) görülmüştür. İçsel pazarlama, iş tatmini ve işten ayrılma niyeti değişkenleri arasındaki ilişkiler araştırmalara ayrı ayrı konu olmuşken, hem spor ve fiziksel etkinlik sektöründen hem de diğer sektörlerden bu değişkenler arasında üçlü bağlantıları inceleyen herhangi bir ampirik araştırmaya rastlanılmamıştır.

Literatür incelendiğinde işten ayrılma niyeti üzerinde etkili olan birçok değişkenin olduğu görülmektedir. İçsel pazarlama ve iş tatmini bunlardan biridir. İçsel pazarlama çalışanların beklenti ve ihtiyaçlarının karşılanmasını sağlayan faaliyetleri kapsarken, iş tatmini çalışanlarda oluşan duygusal değerlendirmelerden oluşmaktadır. Dolayısıyla içsel pazarlama, iş tatmininin oluşmasında ve aynı zamanda işten ayrılma niyetinin azaltılmasında etkili olan önemli bir değişken olarak değerlendirilmektedir. Ancak, işten ayrılma niyeti üzerinde hangi değişkenin doğrudan, hangi değişkenin dolaylı etkisi olduğu ise bilinmemektedir. Buradan hareketle, bu üç değişken arasındaki sebep sonuç ilişkilerinin netleştirilebilmesi, başka deyişle iş tatmininin aracı değişken olarak ele alındığı, içsel pazarlama ile işten ayrılma niyeti arasındaki ilişkilerin belirlenmesi amacıyla aşağıdaki hipotezler geliştirilmiştir:

$\mathrm{H}_{1}$ : İçsel pazarlamanın antrenörlerin iş tatminine anlamlı ve pozitif etkisi vardır.

$\mathrm{H}_{2}$ : İ̧sel pazarlamanın antrenörlerin işten ayrılma niyetine anlamlı ve negatif etkisi vardır.

$\mathrm{H}_{3}$ : Iş̧ tatmininin içsel pazarlama ve işten ayrılma niyeti arasında aracılık etkisi vardır.

\section{YÖNTEM}

\subsection{Araştırma Modeli}

Spor ve fiziksel etkinlik işletmeleri bağlamında, içsel pazarlamanın iş tatmini ve işten ayrılma niyeti üzerindeki rolünü incelemek amacıyla yapılan bu araştırmanın modeli Şekil 1'de sunulmuştur. Bu model değişkenler arasında neden sonuç ilişkisini, yani bağımsız değişkenin aracı değişkene, bağımsız değişkenin bağımlı değişkene ve aracı değişkenin bağımlı değişkene olan etkisini göstermektedir. Burada aracı değişkenin etkisi kontrol edildiğinde bağımsız değişken ile bağımlı değişken arasındaki ilişkinin düzeyine bakılır. İlişki düzeyinde düşüş olması ve anlamlılığın devam etmesi "kısmi aracılığı", ilişkinin anlamlı çıkmaması ise "tam aracılı̆ı" gösterir. Diğer taraftan aracı değişken ile bağımlı değişken arasındaki anlamlılık düzeyinin de korunması gerekir (Baron ve Kenny, 1986).

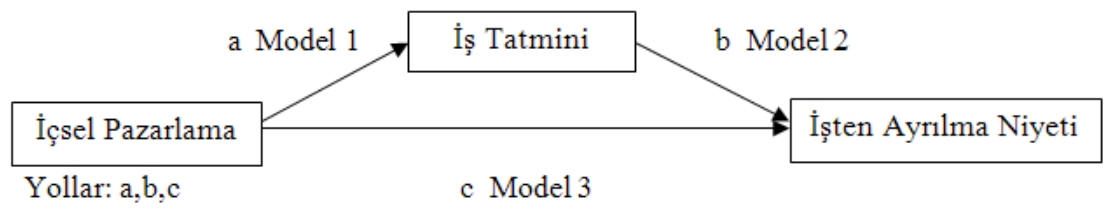

Şekil 1: İçsel Pazarlama, İş Tatmini ve Iş̧ten Ayrılma Niyeti Ilişsisi

\section{2. Ölçme Araçları ve Örneklem}

Araştırmada veri toplama aracı olarak; Foreman ve Money'in (1995) içsel pazarlama ölçeği, Chang ve Chang'ın (2007) iş tatmini ölçeği, Landau ve Hammer'in (1986) işten ayrılma niyeti ölçeği kullanılmıştır. Orijinal ölçekler araştırmacı tarafından Türkçe'ye çevrilmiş ve ayrıca alan uzmanlarına da kontrol ettirilmiştir. Gerekli düzeltmeler yapıldıktan sonra ölçekler uygulama formu haline getirilmiştir. Her üç ölçekteki ifadeler ("1=Hiç katılmıyorum", "2=Katılmıyorum", "3=Kararsızım", "4=Katılıyorum", "5=Tamamen katılıyorum"dan oluşan) Likert tipi 5 'li derece ile ölçülmüştür.
Araştırmanın örneklemini İstanbul'da ticari olarak faaliyet gösteren fitness işletmeleri oluşturmuştur. 500 ölçek formu araştırmacı tarafından fitness antrenörlerine dağıtılmış ve yanıtlamaları için bir hafta süre verilmiştir. Bir hafta sonra formlar tekrar toplanmıştır. Toplanan formların 176 olduğu tespit edilmiştir (geri dönüş oranı \%35,2). İnceleme sonucunda bazı eksiklikleri görülen 34 form analizlere dahil edilmemiş, tam olarak dolduruldukları görülen 142 form analiz için uygun bulunmuştur.

\section{3. İstatistiksel Analiz}

Katılımcıların demografik özelliklerini ortaya koymakiçin frekans veyüzdehesaplamalarıyapılmıştır. Ölçeklerin yapı geçerliğini teyit etmek için Doğrulayıcı 
Faktör Analizi, değişkenler arasındaki ilişkinin yönünü ve kuvvetini belirlemek için Korelasyon Analizi, birden fazla değişkenin diğer bir değişken üzerindeki etkilerini belirlemek için Hiyerarşik Regresyon Analizi kullanılmıştır.

\section{BULGULAR}

\subsection{Demografik Özellikler}

Araştırmada yer alan katılımcıların $(N=142)$ yarıdan fazlasını erkekler oluştursa da bayanların da yarıya yakın olduğu görülmektedir. Ayrıca, katılımcıların \% 80'i bekar olup, en fazlası 21-30 yaş aralığındadır. Eğitim durumuna göre ise büyük çoğunluğu üniversite mezunları oluşturmaktadır. Katılımcıların \%70'i 5 yıl ve daha altındaki çalışma sürelerine sahiptir (Tablo 1).

Tablo 1: Demografik Özellikler

\begin{tabular}{|l|l|c|c|}
\hline Değişkenler & Kategori & Frekans & Yüzde (\%) \\
\hline \multirow{3}{*}{ Cinsiyet } & Erkek & 75 & 52,8 \\
\cline { 2 - 4 } & Kadın & 67 & 47,2 \\
\hline \multirow{4}{*}{ Yedeni Durum } & Evli & 29 & 20,4 \\
\cline { 2 - 4 } & Bekar & 113 & 79,6 \\
\hline \multirow{4}{*}{ Eğitim Durumu } & 20 ve altı & 4 & 2,8 \\
\cline { 2 - 4 } & $21-30$ & 114 & 80,3 \\
\hline & Lise & 20 & 14,1 \\
\cline { 2 - 4 } & Üniversite & 4 & 2,8 \\
\hline \multirow{5}{*}{ Çalışma Süresi } & 41 ve üstü & 7 & 4,9 \\
\cline { 2 - 4 } & 5 yıl ve altı & 99 & 95,1 \\
\cline { 2 - 4 } & $6-10$ yıl & 35 & 24,6 \\
\cline { 2 - 4 } & $11-15$ yıl & 5 & 3,5 \\
\cline { 2 - 4 } & $16-20$ yıl & 2 & 1,4 \\
\cline { 2 - 4 } & 21 yıl ve üstü & 1 & 0,7 \\
\hline
\end{tabular}

\subsection{Geçerlik Analizi Sonuçları}

İçsel pazarlama, iş tatmini ve işten ayrılma niyeti ölçeklerinin yapı geçerliliğini teyit etmek amacıyla kullanılan Doğrulayıcı Faktör Analizi sonuçlarına göre ölçeklere ait indekslerin iyi uyum özelliklerine sahip olduğu görülmektedir (Tablo 2).

\subsection{Korelasyon ve Hiyerarşik Regresyon Analizi Sonuçları}

Korelasyon analizi sonuçları, içsel pazarlama ile iş tatmini arasında anlamlı ve pozitif bir ilişkiyi $(r=0,731)$; işten ayrılma niyeti ile içsel pazarlama arasında anlamlı ve negatif bir ilişkiyi $(r=-0,554)$; ve benzer şekilde işten ayrılma niyeti ile iş tatmini arasında anlamlı ve negatif bir ilişkiyi $(r=-0,703)$ göstermektedir. Buna göre, tüm değişkenler arasında güçlü ilişkilerin söz konusu olduğu söylenebilir (Tablo 3).

Diğer taraftan Model 1'de içsel pazarlamanın bağımsız değişken, iş tatmininin bağımlı değişken; Model 2'de içsel pazarlamanın bağımsız değişken, işten ayrılma niyetinin bağımlı değişken; Model 3'te içsel pazarlamanın ve iş tatmininin bağımsız değişken, işten ayrılma niyetinin ise bağımlı değişken olarak ele alındığı hiyerarşik regresyon analizi sonuçlarına göz atıldığında, Model 2'de $-0,576$ olan içsel pazarlamanın $\beta$ değerinin Model 3'te -0,146'ya düştüğü ve anlamlılığını yitirdiği görülmüştür $(p>0,05)$. $\quad \beta$ değerindeki bu düşüş ve anlamlılığı yitirme, bununla birlikte aracı değişkenin anlamlılığını koruması durumu, iş tatmininin, içsel pazarlama ve işten ayrılma niyeti arasında tam aracılık etkisi olduğunu göstermektedir.

Sonuç olarak, elde edilen tüm bu bulgulara göre hipotez 1, hipotez 2 ve hipotez 3 kabul edilmiştir. Öte yandan korelasyon analizinde yer alan demografik değişkenler içerisindeki çalışma süresinin işten ayrılma niyeti üzerindeki anlamlılığı regresyon analizinde ortadan kalkmış, medeni durumunun anlamlı etkisi ise devam etmiştir. Buna göre medeni durumun işten ayrılma niyeti üzerinde etkili olan diğer bir değişken olduğu söylenebilir (Tablo 4).

Tablo 2: Ölçeklere Ait Doğrulayıcı Faktör Analizi Sonuçları

\begin{tabular}{|l|c|c|c|c|c|c|c|}
\hline Ölçekler & $\chi^{2}$ & $\mathrm{df}$ & $\chi^{2} / \mathrm{df}$ & GFI & AGFI & CFI & RMSEA \\
\hline İçsel Pazarlama & 159,15 & 54 & 2,95 & 0,91 & 0,85 & 0,95 & 0,07 \\
\hline İş Tatmini & 92,36 & 32 & 2,89 & 0,94 & 0,89 & 0,97 & 0,06 \\
\hline Işsten Ayrılma Niyeti & 10,2 & 6 & 1,70 & 0,96 & 0,91 & 0,99 & 0,03 \\
\hline
\end{tabular}


Tablo 4: Hiyerarşik Regresyon Analizi Sonuçları

\begin{tabular}{|c|c|c|c|}
\hline \multirow[t]{2}{*}{ DEĞişKENLER } & İş Tatmini & $\begin{array}{c}\text { İşten } \\
\text { Ayrılma } \\
\text { Niyeti }\end{array}$ & $\begin{array}{l}\text { Isşten } \\
\text { Ayrılma } \\
\text { Niyeti }\end{array}$ \\
\hline & $\beta$ & $\beta$ & $\beta$ \\
\hline \multicolumn{4}{|l|}{ Model 1} \\
\hline Cinsiyet &,- 033 & & \\
\hline Medeni durum &,- 120 & & \\
\hline Yaş &,- 010 & & \\
\hline Eğitim &,- 027 & & \\
\hline Görev &,- 102 & & \\
\hline Çalışma süresi & ,043 & & \\
\hline Statü &,- 084 & & \\
\hline İçsel Pazarlama &, $722^{*}$ & & \\
\hline $\mathrm{F}$ & 21,247 & & \\
\hline $\mathrm{R}^{2}$ & ,561 & & \\
\hline Düzeltilmiş $\mathrm{R}^{2}$ & ,535 & & \\
\hline \multicolumn{4}{|l|}{ Model 2} \\
\hline Cinsiyet & &,- 013 & \\
\hline Medeni durum & & $248^{* *}$ & \\
\hline Yaş & & ,049 & \\
\hline Eğitim & & ,077 & \\
\hline Görev & & ,001 & \\
\hline Çalışma süresi & &,- 110 & \\
\hline Statü & & ,059 & \\
\hline İçsel Pazarlama & &,$- 576^{*}$ & \\
\hline $\mathrm{F}$ & & 10,723 & \\
\hline $\mathrm{R}^{2}$ & & ,392 & \\
\hline Düzeltilmiş $\mathrm{R}^{2}$ & & ,356 & \\
\hline \multicolumn{4}{|l|}{ Model 3} \\
\hline Cinsiyet & & &,- 032 \\
\hline Medeni durum & & &, $176^{* * * *}$ \\
\hline Yaş & & & ,043 \\
\hline Eğitim & & & 060 \\
\hline Görev & & &,- 060 \\
\hline Çalışma süresi & & &,- 085 \\
\hline Statü & & & ,009 \\
\hline İçsel Pazarlama & & &,- 146 \\
\hline İş Tatmini & & &,$- 596^{*}$ \\
\hline $\mathrm{F}$ & & & 17,766 \\
\hline $\mathrm{R}^{2}$ & & & ,548 \\
\hline Düzeltilmiş $\mathrm{R}^{2}$ & & &, 517 \\
\hline
\end{tabular}
iş tatmini ve işten ayrılma niyeti üzerinde etkili olan önemli bir olgu olduğunu göstermektedir. Araştırmanın sonuçlarına göre, içsel pazarlama çalışanların iş tatminini pozitif yönde etkilemekte iken, içsel pazarlama ve iş tatmini çalışanların işten ayrılma niyetini negatif yönde etkilemektedir. İş tatmini aracı değişken olarak ele alındığında, içsel pazarlama ve işten ayrılma niyeti arasında tam aracilık etkisi göstermektedir. Yani, iş tatmini işten ayrılma niyetini doğrudan etkilerken, içsel pazarlama işten ayrılma niyetini dolaylı olarak etkilemektedir.

İçsel pazarlamanın çalışanların iş tatmini üzerinde pozitif etkileri, içsel pazarlama ve iş tatmininin çalışanların işten ayrılma niyeti üzerinde ise negatif etkileri değişik araştırmalarla ortaya konulmuştur. Örneğin, Hwang ve Chi'nin (2005) konaklama sektöründe yaptıkları araştırmalarında $(r=0,86)$, Chang ve Chang'in (2007) sağlık sektöründe yaptıkları araştırmalarında $(r=0,52)$ içsel pazarlama ile iş tatmini arasında anlamlı ve pozitif yönde kuvvetli ilişkiler bulmuştur. Chang ve Chang'in (2008) turizm ve otelcilik sektöründe yaptıkları araştırmalarında, içsel pazarlama uygulamalarının (eğitim ve gelişim ( $r=-$ $0,477)$, performans bilgi sistemi $(r=-0,452)$, yönetim desteği ve katılım $(r=-0,431)$, yetenek geliştirme $(r=-$ $0,455)$, dikkate alma $(r=-0,386)$, yetkilendirme $(r=-$ 0,441 ) boyutlarının) çalışanın işten ayrılma niyetini anlamlı ve negatif etkilediğini bulmuştur. Chatzoglou vd.'nin (2011) muhasebe sektöründe $(r=-0,32)$, Liu, Liu ve Hu'nun (2010) yükseköğretim sektöründe $(r=-0,581)$, Akın'ın (2007) muhasebe sektöründe ( $r=-$ 0,427), Yorgun, Yllmaz ve Keser'in (2009) konaklama sektöründe $(r=-0,50)$ yaptıkları araştırmalarında iş tatmini ve çalışanların işten ayrılma niyeti arasında anlamlı ve negatif ilişkiler bulmuşlardır. Yukarıda görüleceği üzere değişik sektörlerde yapılan araştırmalardaki bulgular ile araştırmamızdaki bulgular örtüşmektedir. Diğer araştırmalardan farklı olarak, bu araştırma, iş tatmininin içsel pazarlama ile işten ayrılma niyeti arasında tam aracılık etkisini de ortaya koymaktadır. Buna göre, çalışanlarda işten ayrılma niyetinin oluşmaması için öncelikle onların iş tatmininin sağlanması gerekmektedir. İçsel pazarlama ise, çalışanlarda iş tatmininin oluşmasında önemli bir değişken olarak karşımıza çıkmaktadır.

Öte yandan bu araştırma demografik değişkenler içerisinde yer alan medeni durumun işten ayrılma niyeti üzerinde etkili olan diğer bir değişken olduğunu da ortaya koymaktadır. Buna göre bekar çalışanların işten ayrılma niyeti evli çalışanlara göre daha yüksektir. Bu durumun temelinde bekarlarda 


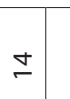

$m$

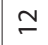

$=$

$\circ$

$\sigma$

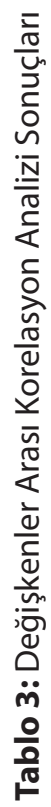

$\infty$

$N$

$\bullet$

n

$\checkmark$

$m$

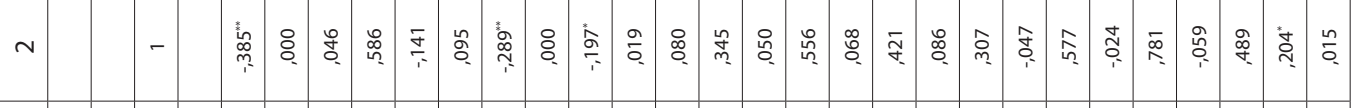

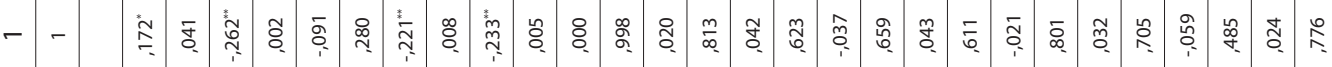

\begin{tabular}{|c|c|c|c|c|c|c|c|c|c|c|c|c|c|c|c|}
\hline 只 & in & q & in & $\bar{ָ}$ & ถู & ஜㅁ & ซุ & $\stackrel{0}{1}$ & 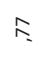 & ఇু & $\stackrel{?}{\Omega}$ & $\stackrel{\varrho}{0}$ & $\overline{0}$ & $\infty$ & $\stackrel{n}{=}$ \\
\hline$\Sigma$ & 호 & $\stackrel{શ}{=}$ & $\frac{0}{N}$ & $\stackrel{\swarrow ٌ}{=}$ & 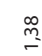 & $\stackrel{\overbrace{}}{\approx}$ & 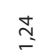 & $\underset{\text { }}{\stackrel{g}{r}}$ & $\bar{q}$ & $\underset{m}{\stackrel{\Omega}{m}}$ & $\underset{\sigma}{+}$ & $\frac{\Omega}{\sigma}$ & 孚 & $\stackrel{\substack{q \\
\sigma}}{ }$ & $\stackrel{i}{i}$ \\
\hline
\end{tabular}

뚤

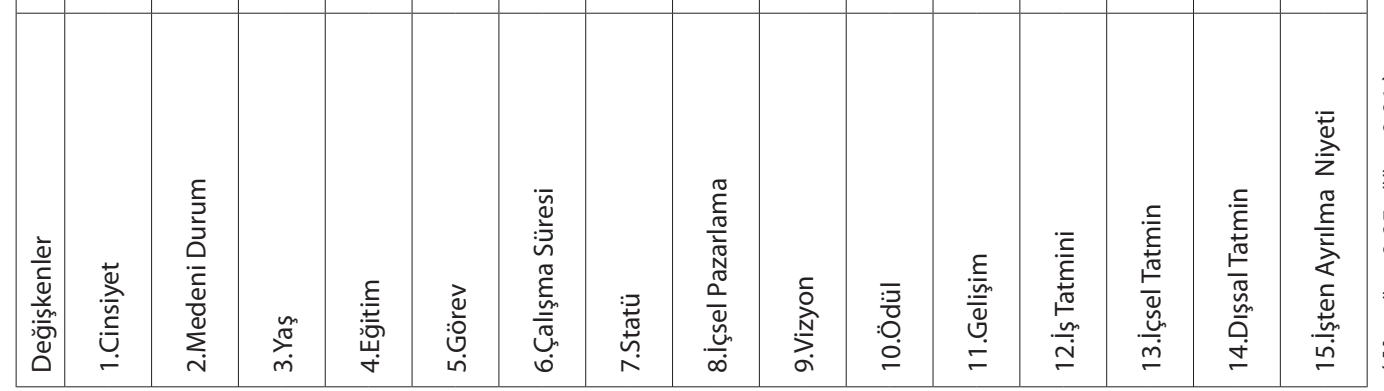

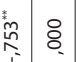

点

空

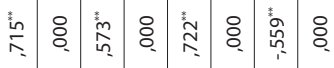

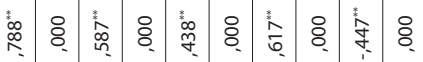

吾 \&

密

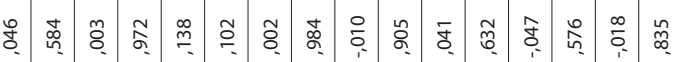

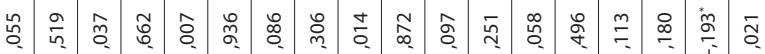

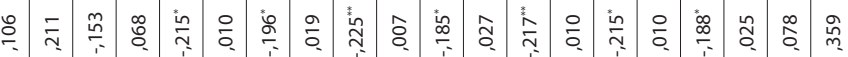

英㤐

兽 并 
aile sorumluluğunun olmaması yatıyor olabilir. Başka deyişle, evlilerin aile geçindirme gibi bir hassasiyeti ve sorumluluğu taşıyor olmaları işten ayrılma niyetini azaltıyor olabilir.

Sonuç olarak, içsel pazarlamanın bir boyutuyla çalışanlarda müşteri odaklılığı oluşturduğu, bunun da daha kaliteli hizmet ile (Cooper ve Cronin, 2000) dış müşteri tatmini ve sadakatini sağladığı (Barnes, Fox ve Morris, 2004), diğer boyutuyla personel devir hızını düşürdüğü (Arnett vd., 2002), oluşan istikrarlı hizmetin işletme performansını pozitif etkilediği (Bouranta, Mavridoglou ve Kyriazopoulos, 2005) göz önüne alındığında, içsel pazarlama faaliyetlerinin spor ve fiziksel etkinlik sektöründe yer alan tüm işletmeler tarafından uygulanması önerisi verilebilir. Çalışanların işten ayrılma niyetlerini azaltmak için, içsel pazarlama yoluyla çalışanların eğitim ve gelişimleri ile yüksek performans gösterenlerin ödüllendirilmeleri sağlanarak iş tatminleri artırılmalıdır. Bir nevi işletme performansı göstergesi olan hizmet kalitesi, dış müşteri tatmini ve sadakati bu yolla sağlanabilir. 


\section{SON NOTLAR}

Bu çalışma Muğla Sıtkı Koçman Üniversitesi Bilimsel Araştırma Birimi tarafından desteklenmiştir

\section{KAYNAKLAR}

Ahmed, P.K., Rafiq, M. ve Saad, N.M. (2003) “Internal Marketing and the Mediating Role of Organisational Competencies" European Journal of Marketing, 37(9): 1221-1241.

Ahmad, N., Iqbal, N. ve Sheeraz, M. (2012) "The Effect of Internal Marketing on Employee Retention in Pakistani Banks" International Journal of Academic Research in Business and Social Sciences, 2(8): 270-280.

Arnett, D.B., Laverie, D.A. ve Mclane, C. (2002) "Using Job Satisfaction and Pride asInternal-Marketing Tools" Cornell Hotel and Restaurant Administration Quarterly, 43(4): 87-96.

Akın, A. (2007) "Muhasebe Meslek Mensuplarında İş Tatmini ile İşten Ayrılma Niyeti Eğilimi Arasındaki İlişkinin İncelenmesi” Muhasebe ve Finansman Dergisi, 34: 144-151.

Barnes, B.R., Fox, M.T. ve Morris, D.S. (2004) "Exploring the Linkage Between Internal Marketing, Relationship Marketing and Service Quality: A Case Study of a Consulting Organization" Total Quality Management, 15(5-6): 593-601.

Baron, R.M. ve Kenny, D.A. (1986) "The ModeratorMediator Variable Distinction in Social Psychological Research: Conceptual, Strategic, and Statistical Considerations" Journal of Personality and Social Psychology, 51(6): 1173-1182.

Berry, L.L. (1995) "Relationship Marketing of Services-Growing Interest, Emerging Perspectives" Journal of the Academy of Marketing Science, 23(4): 236-245.

Bouranta, N., Mavridoglou, G. ve Kyriazopoulos, P. (2005) "The Impact of Internal Marketing to Market Orientation Concept and Their Effects to Bank Performance" Operational Research: An International Journal. 5(2): 349-362.

Cahill, D.J. (1995) “The Managerial Implications of the Learning Organization: A New Tool for Internal Marketing" Journal of Services Marketing, 9(4): 43-51.

Chang, C.S. ve Chang, H.H. (2007) "Effects of Internal Marketing on Nurse Job Satisfaction and Organizational Commitment: Example of Medical Centers in Southern Taiwan" Journal of Nursing Research, 15(4): 265-274.

Chang, C.P. ve Chang, W.C. (2008) "Internal Marketing Practices and Employees' Turnover Intentions in Tourism and Leisure Hotels" The Journal of Human Resource and Adult Learning, 4(2): 161-172.
Chatzoglou, P.D., Vraimaki, E., Komsiou, E., Polychrou, E. ve Diamantidis, A.D. (2011) "Factors Affecting Accountants' Job Satisfaction and Turnover Intentions: A Structural Equation Model" $8^{\text {th }}$ International Conference on Enterprise Systems, Accounting and Logistics, Thassos Island, Greece.

Cooper, J. ve Cronin, J.J. (2000) "Internal Marketing: A Competitive Strategy for the Long-Term Care Industry" Journal of Business Research, 48(3): 177-181.

Çarıkçı, İ.H. ve Oksay, A. (2004) "Örgütsel Yapı ve Meslek Farklılıklarının İş Tatmini Üzerindeki Etkileri: Hastane Çalışanları Üzerine Bir Araștırma” SDÜ İ.İ.B.F. Dergisi, 9(2): 157-172.

Dess, G.G. ve Shaw, J.D. (2001) "Voluntary Turnover, Social Capital, and Organizational Performance" Academy Managemet Review, 26(3): 446-456.

Foreman, S. ve Money, A. (1995) "Internal Marketing: Concepts, Measurement and Application" Journal of Marketing Management, 11(8): 755-768.

George, W.R. (1990) "Internal Marketing and Organizational Behavior: A Partnership in Developing Customer-Conscious Employees at Every Level" Journal of Business Research, 20(1): 63-70.

Greene, W., Walls, G.D. ve Schrest, L.J. (1994) "Internal Marketing: The Key to External Marketing Success" Journal of Services Marketing, 8(4): 5-13.

Grönroos C. (1990) "Service Management: A Management Focus for Service Competition" International Journal of Service Industry Management, 1(1): 6-14.

Grönroos, C. (1994) "From Marketing Mix to Relationship Marketing: Towards a Paradigm Shift in Marketing" Management Decision, 32(2): 4-20.

Grönroos, C. (2000) "Service Management and Marketing: A Customer Relationship Management Approach" (2nd edition) New York: John Wiley \& Sons.

Gummesson, E. (1987) "The New Marketing: Developing Long Term Interactive Relationships" Long Range Planning, 20(4): 10-20.

Gummesson, E. (1991) "Marketing Orientation Revisited: The Crucial Role of the Part-Time Marketer" European Journal of Marketing, 25(2): 60-75.

Gummesson, E. (2000) "Internal Marketing in the Light of Relationship Marketing and Network Organizations" in Internal Marketing: Directions for Management. R.J. Varey, Lewis, B.R. (Eds) London: Routledge. 
Güney, S. (2012) “Örgütsel Davranı̧»" (2. Baskı) Ankara: Nobel Akademik Yayıncılık Eğitim Danışmanlık Tic. Ltd. Şti.

Hwang, I.S. ve Chi, D.J. (2005) "Relationships Among Internal Marketing, Employee Job Satisfaction and International Hotel Performance: An Empirical Study" International Journal of Management, 22(2): 285293.

Jeon, H. ve Choi, B. (2012) “The Relationship Between Employee Satisfaction and Customer Satisfaction” Journal of Services Marketing, 26(5): 332-341.

Joseph, W.B. (1996) "Internal Marketing Builds Service Quality" Journal of Health Care Marketing, 16(1): 54-59.

Landau, J. ve Hammer, T.H. (1986) "Clerical Employees' Perceptions of Intraorganizational Career Opportunities" Academy of Management Journal, 29(2): 385-404.

Lau, R.S.M. ve May, B.E. (1998) "A Win-Win Paradigm for Quality of Work Life and Business Performance" Human Resource Development Quarterly, 9(3): 211-226.

Lau, R.S.M. (2000) "Quality of Work Life and Performance-An Investigation of Two Key Elements In the Service Profit Chain Model" International Journal of Service Industry Management, 11(5): 422-437.

Lings, I.N. (2004) "Internal Market Orientation: Construct and Consequences" Journal of Business Research, 57(4): 405-413.

Martensen, A. ve Gronholdt, L. (2006) "Internal Marketing: A Study of Employee Loyalty, its Determinants and Consequences" Innovative Marketing, 2(4): 92-116.

Rafiq, M. ve Ahmed, P.K. (1993) "The Scope of Internal Marketing: Defining the Boundary Between Marketing and Human Resource Management" Journal of Marketing Management, 9(3): 219-232.

Rafiq, M. ve Ahmed, P.K. (2000) "Advances in the Internal Marketing Concept: Definition, Synthesis and Extension” Journal of Services Marketing, 14(6): 449-462.

Saari, L.M. ve Judge, T.A. (2004) "Employee Attitudes and Job Satisfaction" Human Resource Management, 43(4): 395-407.

Shiu, Y.-M. ve Yu, T.W. (2010) "Internal Marketing, Organisational Culture, Job Satisfaction, and Organisational Performance in Non-Life Insurance" The Service Industries Journal, 30(6): 793-809.

Staw, B.M. (1980) "The Consequences of Turnover" Journal of Occupational Behaviour, 1: 253-273.
Şahin, F. (2011) “The Effect of Gender on the Relationship Between Leader-Member Exchange and Intention to Quit" Ege Academic Review, 11(2): 277-288.

Wagenheim, M. ve Anderson, S. (2008) "Theme Park Employee Satisfaction and Customer Orientation" Managing Leisure, 13(3-4): 242-257.

Wasmuth, W.J. ve Dawis, S.W. (1983) "Managing Employee Turnover" Cornell Hotel and Restaurant Administration Quarterly, 24(1): 15-22.

Wasmuth, W.J. ve Dawis, S.W. (1993) "Managing Employee Turnover: Why Employees Leave" Cornell Hotel and Restaurant Administration Quarterly, 24(2): 1118.

Watrous, K.M., Huffman, A.H. ve Pritchard, R.D. (2006) "When Coworkers and Managers Quit: The Effects of Turnover and Shared Values on Performance" Journal of Business and Psychology, 21: 103-126.

Wells, J.E. ve Peachey, J.W. (2011) "Turnover Intentions: Do Leadership Behaviors and Satisfaction with the Leader Matter?" Team Performance Management, 17(1/2): 23-40.

Yıldız, S.M. ve Tüfekçi, Ö. (2010) "Fitness Merkezi Müşterilerinin Hizmet Kalitesine Yönelik Beklenti ve Algılarının Değerlendirilmesi” Balıkesir Üniversitesi Sosyal Bilimler Enstitüsü Dergisi, 14(24): 1-11.

Yıldız, S.M.(2011) "İçsel Pazarlama, İş Tatmini ve Örgütsel Bağlılık İlişkisi: Spor Okullarında Görev Yapan Antrenörler Üzerine Bir İnceleme” Selçuk Üniversitesi Beden Eğitimi ve Spor Bilim Dergisi, 13(2): 216-225.

Yildiz, S.M. (2013) “The Effect of Quality of Work Life on Employee Turnover Intention in Sports and Physical Activity Organizations" Ege Academic Review, 13(3): 317-324.

Yin-Fah, B.C., Foon, Y.S., Chee-Leong, L. ve Osman, S. (2010) "An Exploratory Study on Turnover Intention Among Private Sector Employees" International Journal of Business and Management, 5(8): 57-64.

Yorgun, S., Yilmaz, G. ve Keser, A. (2009) "The Relationships of Job and Life Satisfaction with Intention to Leave Among Unionized Hotel Employees in Turkey" IS, GUC Industrial Relations and Human Resources Journal. 11(2): 55-68.

http://www.wf1broward.com/upload/2261/High_ cost_of_Employee_Turnover-jm514.pdf, (Erişim, 07.Ekim.2012) 